DOI: 10.32844/2222-5374-2020-104-2.40

УДК: 343.98

Гірук В. В.,

здобувач кафедри криміналістики та судової медицини

Національної академії внутрішніх справ

\title{
ДОПИТ МАЛОЛІТНІХ ПОТЕРПІЛИХ ВІД НАСИЛЬНИЦЬКИХ ЗЛОЧИНІВ: ТАКТИЧНІ ОСОБЛИВОСТІ ТА ПРОЦНСУАЛЬНІ ЗАСАДИ
}

Актуальність статті полягає в тому, що упродовж останніх років головним та визначальним у багатьох сферах розвитку суспільного життя України є вектор європейської інтеграції. Прагнення України побудувати з Європейським Союзом відносини не лише на грунті партнерства і співробітництва, але і створити політичні асоціації та здійснити економічні інтеграції, передбачають певну адаптацію та внутрішні реформи. В умовах таких трансформаційних процесів на євроінтеграційному шляху важливе місце займає нормативно-правовий захист прав людини та громадянина. Певну специфічну категорію в даному випадку становлять діти, оскільки внаслідок певних вікових особливостей розвитку вони не здатні самостійно, в повному обсязі розуміти, користуватись та інформувати про випадки не дотримання їх прав та законних інтересів. Під час розслідування кримінальних правопорушень, вчинених відносно малолітніх осіб, перед слідчим також постає ряд проблем, пов'язаних із забезпеченням дотримання прав та законних інтересів досліджуваної категорії. Найчастіше такі проблемні аспекти виникають саме під час організації та проведення допиту малолітнього. В такому випадку, перед слідчим, окрім основного завдання, яке полягає у отриманні від допитуваної особи найбільш повної інформації про подію злочину, постає проблема, яка стосується регулювання психоемоційного клімату у якому проходитиме допит. У статті досліджено окремі аспекти тактичних особливостей допиту малолітніх потерпілих від насильнищьких злочинів. Проаналізовано можливості проведення допиту малолітньої особи у режимі відеоконференції, процесуальні засади залучення психологів та педагогів. Визначено типові ознаки протидії розслідуванню, яка може виникати під час розслідування кримінальних проваджень у яких потерпілими виступають малолітні особи. Окреслено основні завдання, які постають перед слідчим на різних стадіях проведення допиту малолітніх потерпілих від насильницьких злочинів. Досліджено типові тактичні прийоми, які застосовуються в під час допиту малолітніх потерпілих від насильницьких злочинів.

Ключові слова: допит, малолітній потерпілий, насильницькі злочини, тактика слідчих (розшукових) дій.

Актуальність теми. Упродовж останніх років головним та визначальним у багатьох сферах розвитку суспільного життя України є вектор 
європейської інтеграції. Прагнення України побудувати з Європейським Союзом відносини не лише на грунті партнерства і співробітництва, але і створити політичні асоціації та здійснити економічні інтеграції, передбачають певну адаптацію та внутрішні реформи. В умовах таких трансформаційних процесів на євроінтеграційному шляху важливе місце займає нормативно-правовий захист прав людини та громадянина. Певну специфічну категорію в даному випадку становлять діти, оскільки внаслідок певних вікових особливостей розвитку вони не здатні самостійно, в повному обсязі розуміти, користуватись та інформувати про випадки не дотримання їх прав та законних інтересів.

Під час розслідування кримінальних правопорушень, вчинених відносно малолітніх осіб, перед слідчим також постає ряд проблем, пов'язаних із забезпеченням дотримання прав та законних інтересів досліджуваної категорії. Найчастіше такі проблемні аспекти виникають саме під час організації та проведення допиту малолітнього. В такому випадку, перед слідчим, окрім основного завдання, яке полягає у отриманні від допитуваної особи найбільш повної інформації про подію злочину, постає проблема, яка стосується регулювання психоемоційного клімату у якому проходитиме допит.

Стан дослідження. Теоретичним підгрунтям дослідження стали роботи таких учених як В. П. Бахін, В. К. Весельський, А. Ф. Волобуєв, В. І. Галаган, В. Г. Гончаренко, О. Н. Колесніченко, В. О. Коновалова, В. С. Кузьмічов, Є. Д. Лук'янчиков, М. В. Салтевський, Л. Д. Удалова, Ю. М. Чорноус, В. Ю. Шепітько, та ін.

Метою статті є дослідження актуальних проблем, пов'язаних тактичними особливостями та процесуальним забезпеченням допиту малолітніх потерпілих від насильницьких злочинів.

Виклад основного матеріалу. Комплексний підхід до проблем допиту малолітніх потерпілих від насильницьких злочинів передбачає не тільки детальний аналіз тактичних засад досліджуваної слідчої (розшукової) дії, але і розгляд її процесуальних особливостей. Вважаємо, що законодавчий корпус насправді здійснив вагомий внесок щодо захисту прав дітей у кримінальному процесі. Велика частина новел стосується саме статусу неповнолітніх у кримінальному провадженні. Зокрема, у ст. 10 КПК України передбачено, що певні категорії осіб, у тому числі неповнолітні учасники кримінального провадження користуються додатковим гарантіями, а саме [1, с. 137$]$.

По-перше, це стосується особливої процедури допиту неповнолітніх та малолітніх осіб. При проведенні слідчих (розшукових) дій за участю малолітньої особи забезпечується участь законного представника, педагога або психолога, а за необхідності - лікаря. У науковій літературі обгрунтовується думка, що для створення сприятливої обстановки, комфорту та захищеності запрошується той педагог, який безпосередньо знає та навчає допитуваного [1, с.137]. За участю психолога допит малолітнього потерпілого проводиться в разі, якщо внаслідок вчиненого кримінального правопорушення малолітньому завдано певних моральних страждань - таких, що призвели до тимчасового хворобливого стану (стрес, постійне перебування у стані страху тощо) [1, с. 137]. Лікар залучається для проведення 
допиту малолітнього потерпілого, якщо за наслідками вчиненого кримінального правопорушення, потерпілим якого він був, у останнього виникли тимчасові розлади психічної діяльності чи фізичні розлади здоров'я [2, c. 155$]$.

По-друге, до неповнолітньої особи не може бути застосований такий захід забезпечення кримінального провадження як привід.

По-третє, обговорюваним у наукових колах нововведенням КПК України, є допит малолітнього потерпілого у режимі відеоконференції при трансляції з іншого приміщення (дистанційне досудове розслідування) [1, c. 137]. Наведена можливість направлена на захист малолітніх осіб, забезпечення їх безпеки,їх морального здоров'я, мінімізацію їх психологічного травмування, виключення можливості вплинути на об'єктивні і повні показання. Це дає змогу уникнення прямого візуального контакту малолітніх з підозрюваними, обвинуваченими та іншими особами, які можуть тим чи іншим способом негативно вплинути на них і, відповідно, на повноту і достовірність їх показань.

По-четверте, необхідно підкреслити, що насправді, з'явилась ще одна новела. Тепер у прокурора, слідчого є можливість усунути законного представника неповнолітнього від участі у проведенні слідчих (розшукових) дій. Це може бути зроблено не лише за клопотанням, а й з власної ініціативи особи, яка проводить досудове розслідування. Однак для цього повинні бути вагомі причини, оскільки це робиться лише у виняткових випадках, i замість нього призначається інший представник [3, с. 113].

Водночас, сьогодні аналіз чинного кримінального процесуального законодавства України вказує на те, що законодавець, орієнтуючись на міжнародно-правові норми, забезпечує безпрецедентний захист та розширення прав осіб, що вчинили злочин, тоді як потерпілі від злочинів, зокрема, діти-жертви злочинів, залишаються без належної державної допомоги та уваги [4, с. 11]. Погоджуючись з наведеною точкою зору, та, розвиваючи їі, зауважимо, що процесуальна процедура допиту малолітніх потерпілих осіб має деякі, на нашу думку, прогалини. Закріплюючи наведені вище немаловажні гарантії, законодавець не визначив механізму їх реалізації, що має суттєве значення, в тому числі для тактично правильного та ефективного проведення допиту малолітніх потерпілих від насильницьких злочинів [1, c. 138]. Зокрема:

1) Закон не визначає ситуації, в яких повинен бути залучений педагог або психолог; вимоги, яким повинні відповідати останні; з якою метою запрошується педагог (психолог); порядок відшкодування витрат останнім у зв'язку з участю у слідчій дії; не зобов'язує конкретні установи щодо надання таких послуг для участі вказаних спеціалістів у досудовому розслідування. В результаті, виникає дві, на наше переконання, проблеми: по-перше, пошук згаданих спеціалістів для участі у процесуальній дії стає «головним болем» слідчого; по-друге, участь психолога (педагога) носить формальний характер, оскільки останні приймають участь у слідчій дії на безоплатній основі. Як наслідок, слідчий не отримує реальної допомоги від спеціалістів під час допиту у встановленні психологічного контакту і застосуванні вірної тактики допиту з метою отримання повних та об'єктивних показань [1, с.138]. 
Нам видається, законодавець формально поставився до згаданих питань. I це дійсно $є$ реальною організаційною проблемою, з якою стикаються слідчі, і потребує негайного вирішення на законодавчому рівні. Отже, на нашу думку, доцільно доповнити КПК України нормами, які зобов'яжуть органи державної влади та місцевого самоврядування або інші установи забезпечити участь у кримінальному провадженні за участю малолітніх осіб (в даному випадку потерпілих) кваліфікованих фахівців (педагогів, психологів та інших спеціалістів) на вимогу слідчого [1, с. 138].

Необхідно також більш докладно встановити, який же статус лікаря при проведенні слідчих (розшукових) дій за участю малолітнього чи неповнолітнього. Лікар залучається за наявності даних про психічне захворювання дитини. До таких випадків слід віднести і розумову відсталість дитини. Та чи залучається лікар разом з педагогом та психологом? 3 огляду на сполучник «або» в ч. 2 ст. 227 КПК України,права спеціалістам роз'яснюються альтернативно педагогу, психологу або лікарю. Логічно постає питання,чи може лікар заміняти одного з цих спеціалістів або їх обох, чи ці спеціалісти, або, знову ж таки, один з них, є обов'язковими учасниками дій за участю неповнолітньої (малолітньої) особи. На це також слід звернути увагу [3, с. 113].

2) Більшість насильницьких злочинів щодо дітей вчинюються в умовах неочевидності, коли потерпілі є єдиним джерелом інформації про подію злочину та особу злочинця. Розслідування вказаних видів насильницьких злочинів та проведення слідчих дій за участю малолітнього потерпілого пов'язано із втручанням в його особисте життя і додатково травмує його психіку, що в подальшому може стати однією з причин відмови потерпілої особи від дачі показань. Запобігти цьому в певній мірі сприятиме вивчення її особистості. Проведення допиту потерпілої від насильницького злочину з урахуванням криміналістично значимої інформації про її демографічні і біографічні, соматичні, біологічні, психологічні, соціальні, супутні дані сприятиме не лише кваліфікованому та ефективному проведенню допиту потерпілої, але й одержанню таких результатів цієї слідчої дії, які матимуть значення для подальшого розслідування кримінальної провадження та встановлення істини. У цьому сенсі автор поділяє погляд Т. П. Матюшкової, яка у дисертаційному дослідженні обгрунтовувала необхідність врахування законодавцем цього факту, зокрема, повинно бути закріплено на законодавчому рівні те, що допит потерпілого повинен здійснюватися $з$ урахуванням одержаних слідчим даних, що характеризують його особистість [5, с. 73].

3) Слід також звернути увагу на закріплену у законодавстві можливість усунути законного представника малолітнього від участі у проведенні слідчих (розшукових) дій. Практика свідчить про непоодинокі випадки, коли законні представники малолітніх потерпілих з числа батьків (опікунів), заважають допиту, впливають на достовірні показання, сприяють виникненню проблем та труднощів під час слідчої дії з різних причин. I знову ж таки виникає питання, де слідчому шукати заміну «таким» законним представникам і, хто може виступати в якості останніх [1, с. 140].

Висновки. Таким чином, можливо дійти висновку, що допит $\epsilon$ найбільш поширеною слідчою (розшуковою) дією під час розслідування май- 
же всіх без винятку кримінальних проваджень, в тому числі і кримінальних проваджень у яких потерпілими виступають малолітні особи, та найбільш оперативно-інформативною слідчою (розшуковою) дією, 3 точки зору швидкого отримання інформації та можливості її перевірки. Водночас процес проведення допиту малолітніх осіб, пов'язаний із значними труднощами, які насамперед стосуються правильної організації та планування зазначеної слідчої (розшукової) дії та вимагають від слідчого не лише ретельної підготовки, а і передбачають наявність відповідних фахових знань та досвіду. Зазначені критерії дозволять слідчому правильно обрати оптимальне місце для проведення допиту; визначити найбільш ефективні та результативні тактичні прийоми, що в свою чергу дозволить встановити психологічний контакт із допитуваною особою, а також визначити коло учасників, присутніх під час допиту.

\section{СПИСОК ВИКОРИСТАНИХ ДЖЕРЕЛ}

1. Гірук В. В. Тактичні та процесуальні засади допиту малолітніх потерпілих від насильницьких злочинів. Актуальні питання кримінального процесу, криміналістики та судової експертиз: матеріали міжвідом. наук.-практ. конф. (Київ, 24 листоп. 2017 р.). Київ, 2017. Ч. 2. С. 137-141.

2. Максимишин Н. М. Судовий допит: процесуальне і криміналістичне дослідження : дис. ... канд. юрид. наук: 12.00.09. Львів, 2016. 250 с.

3. Пилипенко I. Окремі проблеми заст

DOІосування законодавства щодо участі неповнолітніх у кримінальному провадженні. Публічне право. 2013. № 3(11). С. 110-118.

4. Методичні рекомендації щодо опитування дітей, що стали свідками та/або жертвами насильства, а також вчинили насильство: Метод. посіб. / Автори-упоряд.: Д. Пурас, О. Калашник, О. Кочемировська; Т. Цюман; за заг. ред. Т. Цюман. К.: ФОП КЛИМЕНКО, 2015. 114 с.

5. Матюшкова Т. П. Тактика допиту потерпілих-жінок від насильницьких злочинів : дис. ... канд. юрид. наук: 12.00.09. Харків, 2006. 237 с.

6. Удалова Л. Д. Вербальная информация в уголовном процессе Украины: монография. Київ: Вид. ПАЛИВОДА, 2006. 324 с.

7. Чаплинська Ю.А. Підготовка до допиту як необхідна умова якісного проведення слідчої дії. Вісник Академії митної служби України. Серія Право: науковий журнал. 2012. № 2. С. 89-95.

8. Шепитько В.Ю. Допрос несовершеннолетних: психология и тактика: автореферат дис. ... кандидата юридических наук: 12.00.09. Харьков, 1991. 24 c.

9. Шепітько В. Ю. Криміналістична тактика. Системно-структурний аналіз: монографія. Харків, 2007. 431 с.

10. Яремчук В. О. Організація і тактика залучення спеціаліста при проведенні слідчих (розшукових) дій: монографія. Харків: Апостіль, 2015. 228 c. 


\section{Hiruk}

\section{INTERROGATION OF JUVENILE VICTIMS OF VIOLENT CRIMES: TACTICAL FEATURES AND PROCEDURES}

The relevance of the article is that in recent years the main and decisive in many areas of development of public life of Ukraine is the vector of European integration. Ukraine's desire to build relations with the European Union not only on the basis of partnership and cooperation, but also to create political associations and economic integration, presupposes some adaptation and internal reforms. In the conditions of such transformational processes on the European integration path the normative-legal protection of human and civil rights occupies an important place. A certain specific category in this case is children, because due to certain age features of development they are not able to independently, fully understand, use and inform about cases of non-compliance with their rights and legitimate interests. During the investigation of criminal offenses committed against minors, the investigator also faces a number of problems related to ensuring compliance with the rights and legitimate interests of the category under study. Most often, such problematic aspects arise during the organization and conduct of interrogation of a minor. In this case, the investigator, in addition to the main task, which is to obtain from the interviewee the most complete information about the crime, there is a problem concerning the regulation of the psycho-emotional climate in which the interrogation will take place. The article examines some aspects of the tactical features of the interrogation of juvenile victims of violent crimes. Possibilities of conducting interrogation of a minor by videoconference, procedural principles of involvement of psychologists and teachers are analyzed. Typical signs of opposition to the investigation, which may arise during the investigation of criminal proceedings in which the victims are minors, have been identified. The main tasks facing the investigator at different stages of interrogation of juvenile victims of violent crimes are outlined. The typical tactics used during the interrogation of juvenile victims of violent crimes are investigated.

Keywords: interrogation, juvenile victim, violent crimes, tactics of investigative (search) actions. 